Brit. J. vener. Dis. (1964), 40, 196.

\title{
TREATMENT OF NON-GONOCOCCAL URETHRITIS WITH NALIDIXIC ACID (“NEGRAM”)*
}

\author{
BY
}

\author{
R. R. WILLCOX
}

St. Mary's Hospital, London, W.2

Nalidixic acid ("Negram" $\dagger$ ), a new antibacterial agent, is a naphthyridine derivative (1-ethyl-7methyl-1,8-naphthyridin-4-one-3-carboxylic acid), which is unrelated to the sulphonamides, antibiotics, or nitrofurans, and is active particularly against Gram-negative bacteria, including $E$. coli, proteus, aerobacter, and Klebsiella.

This substance is supplied as "Negram" in tablets each of $500 \mathrm{mg}$. for oral administration in a dosage of $4 \mathrm{~g}$. daily for 7 days. Its use in the treatment of thirteen cases of suspected uncomplicated nongonococcal urethritis in males is reported.

\section{Material}

Thirteen male patients with suspected uncomplicated non-gonococcal urethritis were treated with "Negram". Seven were Negroes (six from the West Indies and one from West Africa), three were born in the United Kingdom, two in Eire, and one in Greece. The average age was 30.6 years (range 19 to 51 ). Two were married, ten were single, and one was a widower.

Only five patients had had no previous venereal incident. The remainder had had between them nine previous attacks of gonorrhoea, seven of non-gonococcal urethritis, and one of balanitis. Nine of these seventeen previous attacks had been acquired by the Negro patients only three of whom had had no previous infection.

The discharge had been present for 1-3 days before treatment in six cases, for 4-7 days in four, for 8-14 days in one, and for 15-21 days in two. Eleven patients complained of some dysuria and two did not. The condition had apparently been acquired from a stranger in seven cases and from a friend or acquaintance in six. The apparent incubation period was 1-3 days in one case, 4-7 days in seven, 15-21 days in two, and over one month in three. The Wassermann and VDRL (or Kahn) reactions were negative in all cases as was the gonococcal complement-fixation reaction in the four persons tested.

* Received for publication March 2, 1964.

t Manufactured by the Bayer Products Company, Surbiton-uponThames, Surrey.

\section{Case Management}

Gonococci and trichomonads were excluded by a microscopic examination of stained and wet specimens of the urethral discharge before treatment, and routine serum tests for syphilis were also made. All patients were given tablets of "Negram", to take two $(1 \mathrm{~g}$.) four times a day for 7 days (total $28 \mathrm{~g}$.). An intramuscular injection of $1 \mathrm{ml}$. distilled water was also given at the first visit.

It was planned to see the patients $1,2,4,8$, and 12 weeks from the commencement of treatment, when the urethra was examined for discharge (a smear being taken if present) and the urine for haze and threads. It was intended to make at least one examination of the prostatic secretion during surveillance and to perform final serum tests for syphilis at 3 months. Not all patients attended at the time requested, but at the time of writing this report sufficient time has elapsed for them to be observed for from 3 to 5 weeks after treatment.

\section{Follow-up and Results}

No adverse side-effects were reported. The followup and results so far obtained are noted in the Table.

TABLE

FOLLOW-UP AND RESULTS

\begin{tabular}{|c|c|c|c|c|}
\hline \multirow{2}{*}{ Days } & \multirow{2}{*}{$\begin{array}{l}\text { No. } \\
\text { Followed }\end{array}$} & \multicolumn{3}{|c|}{ Result } \\
\hline & & Satisfactory & $\begin{array}{c}\text { Gonococcal } \\
\text { Infection }\end{array}$ & Failure \\
\hline $\begin{array}{c}0 \\
1-7 \\
8-14 \\
15-21\end{array}$ & $\begin{array}{r}13 \\
11 \\
3 \\
-\end{array}$ & $\begin{array}{r}\overline{3} \\
-\end{array}$ & $\begin{array}{r}\overline{1} \\
2 \\
\end{array}$ & $\begin{array}{r}-4 \\
1 \\
-\end{array}$ \\
\hline Total & 11 & 3 & 3 & 5 \\
\hline
\end{tabular}

Thus, of eleven patients followed, gonococci were subsequently recovered in the urethral smear in three cases. These were presumably cases of gonorrhoea in which gonococci were not detected at first examination although super-infection cannot definitely be excluded. Of the remaining eight cases, failure of 
treatment was noted in five $(62.5$ per cent.). This failure rate is what would be expected if only a placebo was used.

\section{Summary and Conclusions}

(1) Thirteen male patients with suspected nongonococcal urethritis were treated with "Negram", given orally in doses of $4 \mathrm{~g}$. daily to a total $28 \mathrm{~g}$. over 7 days.

(2) In three patients gonococci were found within 2 weeks of starting treatment.

(3) Of the remaining ten patients, eight were followed and "Negram" failed to improve the non-gonococcal urethritis in five $(62.5$ per cent. of those followed). This failure rate is similar to that obtained when only a placebo is used.

(4) "Negram" is unlikely to be of value in the treatment of non-gonococcal urethritis (or of gonorrhoea).
Thanks are expressed to the Bayer Products Co., Surbiton, Surrey, for supplying the "Negram" used in this study.

L'urétrite non-gonococcique traité par l'acide nalidixique (Négram)

\section{RÉSUMÉ}

(1) A 13 hommes qu'on croyait atteints d'urétrite nongonococcique on donna $4 \mathrm{~g}$. par jour (jusqu'à $28 \mathrm{~g}$. en 7 jours) de Négram, un nouveau dérivé antibactérien de la naphthyridine (1-éthyle-7-méthyl-1,8naphthyridin-4-one-3 acide carboxylique).

(2) On trouva des gonocoques chez 3 sujets dans les 15 jours qui suivirent le commencement du traitement.

(3) Sur les 10 autres sujets, 8 furent suivis, et le Négram n'eut aucun effet sur $5(62,5 \%)$. Ce résultat est le même que celui obtenu avec un remède factice.

(4) Le Négram ne semble pas être efficace contre l'urétrite non-gonococcique (ni contre la gonorrhée). 